\title{
THE RMD METHOD WITH COLLABORATIVE WRITING APPROACH TO INCREASING STUDENT'S ABILITY TO CREATE A BOOK
}

\author{
Titin Kustini, Afief Fakhruddin \\ English Department, Universitas Majalengka \\ tienkustini878@gmail.com, afieffakhruddin@unma.ac.id
}

\begin{abstract}
This study, based in university/colleges in Majalengka Regency at the forth semester students held by assumptions that writing ability must be developed continously as part of an effort to create literacy culture in campus. The RMD (Read, Modify and Develop) method is developed from RCM (Read, Check, Modify) method that has succeeded in improving high class students' writing skills in elementary school. The author tried to adapt it to be applied to students college who have higher levels of ability. It combined with the Collaborative Writing approach to make writing learning would be done dynamically, fun and develop students' abilities in writing, analyzing a good narrative and completing publication criteria. The research data was obtained from several ways. It is collected through document analysis, observation, distribution of questionnaires, and conducting interviews. The findings suggest that the students' writing ability was still lacking due to, among others, students still difficult to find ideas and develop essays so that it was necessary to find appropriate methods and approaches to solve these problems. The study concludes that the use of the RMD (Read, Modify and Develop) method combined with Collaborative Writing approach is appropriate to used because it bring up ideas and raise students' creativity and imajination so they able to develop writings. The result of this research proves student's ability in writing increased significantly by using the RMD Method combined with Colaborrative Writing approach so that they able to create a book.

Keywords: writing; read; modify; develop; collaborative
\end{abstract}

\section{ABSTRAK}

Penelitian ini berlangsung di universitas/sekolah tinggi di Kabupaten Majalengka pada mahasiswa semester empat dengan berdasar pada asumsi bahwa kemampuanmenulis harus dikembangkan secara berkesinambungan sebagai salah satu upaya untuk menciptakan budaya literasi di kampus. Metode RMD merupakan pengembangan dari metode RCM yang telah berhasil meningkatkan kemampuan menulis pada siswa SD kelas tinggi. Penulis mencoba mengadaptasinya agar bisa diterapkan pada mahasiswa yang memiliki tingkat kemampuan lebih tinggi. Metode itu dilakukan dengan pendekatan Collaborative Writing untuk membuat pembelajaran writing menjadi lebih menyenangkan dan mampu meningkatkan kemampuan mahasiswa untuk membuat karangan yang layak publikasi. Data penelitian diperoleh dari beberapa cara, yakni melalui analisis dokumen, observasi, kuesioner dan wawancara. Hasil observasi awal, kemampuan menulis mahasiswa masih rendah, mereka sulit menemukan ide dan mengembangkan karangan sehingga perlu dicari metode dan pendekatan yang cocok untuk mengatasinya. Penelitian menyimpulkan bahwa penggunaan metode RMD dikombinasikan dengan pendekatan collaborative writing bisa digunakan karena hal itu memberikan ide dan merangsang imajinasi dan kreatifitas mahasiswa sehingga mereka mampu mengembangkan karangan. Hasil penelitian ini membuktikan kemampuan menulis mahasiswa menigkat signifikan dengan menggunakan metode RMD yang dikombinasikan dengan collaborative writing sehingga mereka mampu membuat buku.

Kata Kunci: writing; read; modify; develop; collaborative

Submitted December 5, 2019 | Revised December 11, 2019 | Accepted December 13, 2019 


\section{Introduction}

Learning English includes four basic things namely Reading, Writing, Listening and Speaking. Writing summarizes the learning experiences of the three components so that they can be proved into writing that is in accordance with the context and structure and rules of language learned. Writing gets reinforcement in the application of literacy culture in schools based on character education. Literacy culture is one measure of educational progress in which learners are accustomed to reading and creating a written work.

Writing

Experts define writing, among others: Djuharie (2005: 120): Writing is a skill that can be nurtured and trained. Djago Tarigan in Elina Syarif, Zulkarnaini, Sumarno (2009: 5): Writing means expressing in writing ideas, opinions, or thoughts and feelings. Lado in Elina Syarif, Zulkarnaini, Sumarno (2009: 5) also expressed his opinion about writing: putting graphic symbols that represent the language understood by others.

Heaton in St. Y. Slamet (2008: 141): Writing is a difficult and complex skill. Gould, Robert DiYanni, and William Smith (1989: 18): Writing a creative act, the act of writing is creative because it requires to interpret or make sense of something: an experience, a text, an event. Writing is creative behavior, creative writing behavior because it requires understanding or feeling something: an experience, writing, events.

McCrimmon in St. Y. Slamet (2008: 141): Writing is an activity of exploring thoughts and feelings about a subject, choosing the things to be written, determining how to write them so that readers can understand them easily and clearly. St. Y. Slamet (2008: 72) expressed his opinion about writing,activities that require complex abilities.

One measure of the progress of education is the creation of a literate society. That's why, literacy culture gets special attention from the government to be developed in schools. Literacy culture is characterized by the increased ability to read and write. Therefore, writing (writing) is a field of learning that must get special attention so that writing is part of the ability of students that can be seen from its output in the form of the ability to write books.

Arranging essays as language skills is a skill to change the shape of the mind into writing. That is why, according to Judge (2004: 15) compiling essays in essence is an effort to express what is seen, experienced, felt, and thought into written language. Meanwhile, according to Gie (1995: 17) composing essays is the whole series of activities of people expressed ideas and convey them through writing language to understand by the readers.

Whereas according to Caraka (1997: 7), composing essays means using language to express the contents of the heart and thoughts in an interesting way that affects the reader. Furthermore Suhendar and Supinah (1993: 110) writing or composing is an activity of expressing ideas in writing, which is different from the activity of expressing ideas orally.

Based on the various definitions above, it can be concluded that composing essays means writing ideas based on the subject matter or topic by words about an object, place, atmosphere or situation coherently.

Steps to Arrange a Framework of writing 
The essay framework according to Widagdho (1994: 138) should be written carefully and detail because it will affect the fluency of the essay. The more careful and detailed the outline is arranged, the better it is for the essay. Based on these thoughts, it can be concluded that the first step in writing an essay is to choose the right topic or main idea. Topics must be determined before writing essays. So, main idea has an important rule on writing.

The second step in composing an essay is to record ideas. This condition is intended so that the ideas that appear are not lost. Furthermore, organize ideas so that existing ideas become systematic in the form of sketches.

RMD Method (Read, Modify and Develop)

The Read, Modify and Develop method is a development of the RCM (Read, Check, Modify) method found by Encon Rahman (2016), a teacher at the Mekarwangi Elementary School in Argapura, who had got the first prize of the National Achievement Teachers in Elementary School Level. This RCM method succeeded in becoming the winner of the National Learning Innovation Contest which led him to got the Princess Maha Chakri Award from the Kingdom of Thailand.

The RCM method has succeeded in improving students' writing skills in high class level of elementary school. The author tried to adapt and develop the RCM method invented by Encon Rahman into Read, Modify and Develop in the hope that it can be applied to students with higher levels of ability.

Collaborative Writing

Collaborative learning provides opportunities to lead to successful learning practices. As technology for learning (technology for instruction), collaborative learning involves active participation of students and minimizing differences between individuals. Collaborative learning has added momentum to formal and informal education from the two powers that met, those are, (1) Realization of practice, that life outside the classroom requires collaborative activity in life in the real world, (2) Grow awareness of social interaction in an effort to realize meaningful learning.

The idea of collaborative learning comes from philosophical perspectives on the concept of learning. To be able to study, one must have a partner. In 1916, John Dewey, wrote a book "Democracy and Education" which contained that the class is a mirror of society and serves as a laboratory for learning about real life. Dewey's main thoughts about education (Jacob et al., 1996), are, (1) Students should be active, learning by doing, (2) Learning should be based on intrinsic motivation, (3) Knowledge is developing, not permanent, (4) Learning activities should be in accordance with the needs and interests of students, (5) Education must include learning activities with the principle of mutual understanding and mutual respect for one another, meaning democratic procedures are very important, (6) Learning activities should relate to the real world and has the aim to develop the world.

Gokhale defines that "collaborative learning" refers to teaching methods in which students in a group vary in their level of ability to work in small groups that lead to shared goals. Term of collaboration means, (1) Keohane believes that collaboration is working together with others, working together, working in one team, and in it mixing in one group towards mutual success, (2) Patel argues that collaboration is a process of functional interdependence in trying to coordinate skills, to coordinate skills, tools, and rewards. 
From the understanding of collaboration expressed by various experts, it can be concluded that the notion of learning collaborative writing is a learning strategy in which students with multilevel variations work together to make one writing in a small group towards a goal that is producing writing that is worthy of publication into a book. In this group students help each other. So the situation of collaborative learning is a positive element of dependence to achieve success.

Thus, we can find out what is emphasized in collaborative learning, that is how to make students in group learning activities occur in the form of cooperation, interaction and information exchange.

The results of preliminary observations, during the English language courses so far, especially in Writing, students still have many difficulties. The difficulties: (1) there are still many students difficult to find ideas for making essays, (2) many errors in the use of language structures include the choice of words and the use of spelling in essays, (2) there are still many irrelevant content relationships, (3) still need improvement how to write paragraph neatly.

Based on the facts that the researchers faced, the next researcher sought a solution so that Writing was easily understood by students at universities / high schools in Majalengka Regency, by learning using a method approach that could provide ideas and guide students to improve their writing skills so that they able to create narrative which can be published as book, using the Collaborative Writing approach with the Read, Modify and Develop (RMD) method.

\section{Method}

This study used an experimental approach (Experimental Research). Experimental research is research that seeks to influence the influence of certain variables on other variables under tightly controlled conditions. According to Latipun (2002), experimental research is a study conducted by manipulation that aims to find out due to manipulation of individuals who are observed. This is a language study in which researchers conduct research on the use of methods and approaches to improve student writing skills in university/colleges in Majalengka Regency.

It conducted in universities/colleges in Majalengka Regency by determining and selecting 3 universities/colleges as sampless. They are the students of Faculty of Teacher Training And Education Science, Majalengka University, YPIB Health College and PUI Islamic College. The research conducted from January to September 2019. The research schedule can be seen in the appendix.

The subject of this study was the 4th semester students at the Faculty of Teacher Training And Education Science, Majalengka University, located on Jl. K.H. Abdul Halim no 103 Majalengka, YPIB Health College, Jl. Gerakan Koperasi No. 12 Majalengka and PUI Islamic College located on Jl. Suma No. 223 Majalengka.

The success of the study was determined by the collaboration of the research team. For this reason, each member of the research team has a description of the tasks that must be carried out. The task description of the lead researcher is (1) responsible for all research activities, (2) making instruments and revising them, (3) processing and analyzing data, and (4) presenting the final report. While the researcher members are assigned as (1) the designer of the learning scenario, (2) 
the implementation of learning activities in the classroom, and (3) helping process and analyze the data.

Data collection

This study spent over eight months of data gathering in five times of class meeting. Data were collected trough observation, questionnaire, and interview, and also the result of their writing. The researchers observe their interest and writing ability before they were given the RMD Method and Collaborative Writing Approach. Participants filled questionnaires before they started to write a narrative and also after they knew how The RMD Method with Collaborative Writing Approach works in narrative writing.

The step of research that has been carried out are preliminary studies conducted by conducting literature studies and interviews and observations of research subjects. Based on the results of the preliminary study, it is known that: (1) the narrative writing ability of fourth semester students is still low because students have difficulty finding essay writing ideas, and (2) students still find it difficult to make essays so they need to find ways to make writing learning fun. Based on the results of preliminary research, it is necessary to find the right method and approach to improve writing skills for students so that writing learning done pleasantly and meaningfully so that in the end of program, their target to be able to make a suitable essay to be published into an ISBN book can be reached.

The session

The study splitted into two process sections. First, the students directed to do RMD method. Second, the students doing collaborative writing. Then, the text was given feedback by the researcher and finally students write the text and give softcopy to be collected become book draft.

Procedure

For the first session, the students practised the RMD Method. The steps were; 1) Students were asked to looking for narrative text from book, magazine, newspaper or browsing. 2) They should have a copy or print out of the text that they used as inspirations. 3) They read it carefully and rewrite the story by their own language and style. 4) The students should develop the text by adding their ideas and imajination.

Then, the students do the collaborative writing. Those are: 1) the students divided into small groups consist three or four students. 2) give enough space among groups to keep their focus. 3) the students read narrative text made by her/his friends and give it a sign for any mistakes like wrong spelling, uncoherent paragraph, etc. 4) the collaborator gave sign in the end of text that have been checked. 5) the students revised their text . 6) the revised text should collected to the researcher and got feedback. 6) the students typed their text after got feedback. 7) the students gave hardcopy and softcopy to be arranged as a draft of book.

Findings

The researcher recorded findings as they occurred in chronological fashion. The preliminary study by observation and interview find out that most of students still difficult in finding ideas when they will start to make a writing. It occurred in three universities/colleges in Majalengka Regency. But after they were introduced to the RMD Method, they solved that problems. 
The students in Majalengka University were the fastest in finding ideas than other colleges. And STAI PUI were the slowest in finding ideas. They needed more than 30 minutes to choose which text that they would be used as inspirations. After they practised the RMD Method, the students's able to increase their ability in writing and STIKES YPIB were the fastest in finishing their writing. They just needed one session to finish their narrative and STAI PUI is the slowest. Most of students of STAI PUI needed more than two session to finish their narrative, but some of them able to finish their narrative in one session like UNMA's students and STIKES YPIB students'.

The speed of students' when they checked their friends' narrative are also vary. But in average they needed one session to finish it.

Some students were still confused how the collaborative writing done but after they practised, it seem that they realize CW enough help them in writing.

Table 1

Participant's Information

\begin{tabular}{ccllll}
\hline University/College & Amount & \multicolumn{2}{c}{ Pre tes } & \multicolumn{2}{c}{ Post test } \\
& & Interest & ability & Interest & ability \\
\hline Majalengka University & 16 & Low & high & High & high \\
STIKES YPIB & 3 & Low & high & High & high \\
STAI PUI & 3 & Low & high & High & high
\end{tabular}

\section{Conclusion}

The study proved that the RMD Method can be solved the students' problem who usually lack of the idea if they want to start make a writing. They had experienced about how the idea growth after they read a narrative text from many sources. In this phase, students who have high motivation in writing, faster than students who have low motivation in writing on find out the narrative text that will be used as inspiration. They need time 15-30 minutes to choose the text as basis in finding idea to write a narrative in new perspectives. The speed of students in finishing their writing are vary. Some students spend one session to finish their text but others need more than one session to finish it. And the RMD Method also suceeded to raising students' idea and imajination to develop the text until it is become new story with the new title.

The researcher belief that the teacher or lecturer can create an atmosphere and a learning context in writing. Collaborative writing gives opportunities for students to learning writing in relax situations, fun and enjoy by working together. Collaborative writing encourages the students to acted as "teachers" and therefore allows pedagogy to become an ingredient within the community. 
The result of this study suggest that the RMD Methods combined with Collaborative Writing approach can be used to increasing students' writing skill in universities/colleges so that they able to produce a narrative text that can be published as an ISBN book. This output also gave students' motivation in writing because they realize make a book is something that important in his/her life.

\section{Bibliography}

Alwasilah, A. Chaedar. (2000). Perspektif Pendidikan Bahasa Inggris di Indonesia dalam Konteks Persaingan Global. Andira: Bandung.

Alwasilah, A. Chaedar. (2005). Pokoknya Menulis: Cara Baru Menulis dengan Metode Kolaborasi. Kiblat: Bandung.

Barnum, Carol M. (1994). "Collaborative Writing in Graduate Technical Communication: Is There a Difference?" Journal of Technical Writing and Communication 24(4):405-419.

Blanton, L.L. (1992). Reading, Writing, and Authority: Issues in Developmental ESL. College ESL, 2(1), 11-19.

Cooper, Melanie. (1995). "Cooperative Learning: An Approach for Large Enrollment Courses." Journal of Chemical Education 72(2):162-164.

Dunn, Dana S. (1996). "Collaborative Writing in a Statistics and Research Methods Course." Teaching of Psychology, Vol. 23, 1996.

Gokhale, Anurdha, A. (1995). Collaborative Learning Enhances Critical Thinking. An Online Article. Available at http://skepdic.com

Graves, D.H. (1994). A fresh look at writing. Portsmouth, New Hampshire: Heinemann.

Louth, Richard, Carole McAllister, and Hunter A. McAllister. (1993). "The Effects of Collaborative Writing Techniques on Freshman Writing and Attitudes." Journal of Experimental Education 61(3):215-224.

Rahman, Encon. (2017). "Metode RCM (Read, Check, Modify) Untuk Meningkatkan Kemampuan Menulis Pada Siswa SD Kelas Tinggi." Submitted for National Teacher Achievement 2017 on level of Teacher's Elementary School.

Ritchie, J., and J. Lewis. (2003). Qualitative research practice. A guide for social science students and researchers. London: Sage. 
Robinson, K. (2001). Out of our minds. Learning to be creative. Chichester: Capstone. 